\title{
IMPLEMENTASI MANAJEMEN BAKAT SEBAGAI SUMBER KEUNGGULAN KOMPETITIF PERUSAHAAN
}

\author{
Suryono Efendi \\ Universitas Nasional, Jakarta \\ Email: suryono.efendi@yahoo.com
}

\begin{abstract}
Abstrak
Organisasi menghadapi masalah dalam manajemen personalia dalam lingkungan bisnis yang dinamis dan kompetitif ini. Untuk bisnis yang berfungsi di tingkat global, manajemen personalia menjadi semakin penting. Tuntutan untuk peran kunci untuk staf terampil kuat karena organisasi mengarahkan mereka dan memimpin organisasi ke tingkat keberhasilan tertinggi. Inilah sebabnya mengapa organisasi berusaha untuk staf terbaik. Tujuan mendasar dari setiap strategi perusahaan adalah membuat kegiatan yang dapat mengarah pada kesuksesan menjadi lebih efektif dan efisien. Ketika bisnis membangun tim yang sangat baik yang terdiri dari staf yang kompeten, manajemen bakat sangat penting.
\end{abstract}

Kata Kunci: Manajemen Bakat, Keunggulan Kompetitif, Perusahaan.

\begin{abstract}
Organizations confront problems in personnel management in this dynamic and competitive business environment. For businesses functioning at a global level, personnel management has become increasingly crucial. The demand for key roles for skilled staff is strong since the organization is to direct them and to lead the organization to the highest level of success. This is why the organization strives for the best staff. The fundamental aim of any corporate strategy is to make the activities that can lead to success more effective and efficiently. When the business builds an excellent team that is comprised of competent staff, talent management is highly crucial.
\end{abstract}

Keywords: Talent Management, Competitive Advantage, Company.

\section{A. PENDAHULUAN}

Manajemen bakat di sektor bisnis dipandang penting karena perusahaan lebih fleksibel dalam pengelolaan personel sebagai faktor yang dihargai (Schuler, 2015). Metode ini tampaknya menjadi semacam pengetahuan tentang bahaya yang akan kehilangan karyawan karena mereka dapat setiap saat menyerahkan diri dan beralih ke perusahaan lain yang menawarkan sesuatu yang lebih besar dan lebih menarik. Manajemen bakat juga dapat membantu perusahaan memanfaatkan personel mereka sebaik mungkin untuk memenuhi tujuan perusahaan (Labola, 2019).

Manajemen bakat adalah serangkaian tindakan yang terkait dengan pemilihan, pengembangan, dan retensi individu-individu yang penting secara strategis (Lewis \& Heckman, 2006). Lebih lanjut mereka menunjukkan bahwa manajemen bakat mengakui orang-orang yang unggul dalam aktivitas dan kinerja tertentu yang mendapat dukungan untuk memungkinkan mereka 'mendorong amplop' sambil menangkap dan berbagi apa yang mereka lakukan secara berbeda sehingga rekan kerja dapat meniru mereka (Lewis \& Heckman, 
2006). Organisasi harus memiliki kemampuan dan kapasitas untuk mengenali orang-orang dan kemampuan yang dapat menciptakan nilai dan memberikan keunggulan kompetitif bagi organisasi; Selain itu, manajemen bakat juga bertujuan untuk mengembangkan dan menempatkan orang yang tepat pada pekerjaan yang tepat pada waktu yang tepat dan menyediakan lingkungan yang tepat untuk menunjukkan kemampuan mereka dengan cara yang terbaik bagi organisasi (Krissetyanti, 2013).

Untuk perusahaan mana pun di lingkungan global, manajemen bakat telah menjadi tantangan terlepas dari negaranya. Selain itu, kekhawatiran umum adalah ketakutan akan kekurangan bakat. Keterampilan yang sama sedang dipromosikan oleh semua organisasi di seluruh dunia. Standarisasi rekrutmen, manajemen, dan pengembangan talenta ditunjukkan oleh tren integrasi global untuk mengamankan keunggulan kompetitifnya di pasar. Oleh karena itu, organisasi menerapkan praktik terbaik dalam manajemen personalia global dan lokal (Sule \& Wahyuningtyas, 2016). Ada beberapa manfaat dari manajemen bakat seperti keterlibatan karyawan, retensi karyawan, peningkatan produktivitas, budaya keunggulan dan banyak lagi (Ballesteros \& Inmaculada, 2010). Keberhasilan organisasi dengan bantuan manajemen bakat berlabuh dalam tiga faktor; faktor-faktor ini adalah pengembangan dan rencana penghargaan, penciptaan jalur karir bagi karyawan berbakat, yang akan membantu dalam memastikan kualitas kerja yang tinggi dalam organisasi yang pada akhirnya akan menghasilkan kinerja yang unggul (Labola, 2019). Organisasi menghadapi masalah dalam manajemen personalia dalam lingkungan bisnis yang dinamis dan kompetitif ini. Untuk bisnis yang berfungsi di tingkat global, manajemen personalia menjadi semakin penting. Persyaratan untuk peran kunci pekerja terampil tinggi, karena merekalah yang akan memimpin organisasi dan memimpin organisasi, oleh karena itu bertujuan untuk orang-orang terbaik (Endratno, 2013).

Teori perusahaan berdasarkan manajemen bakat berhipotesis bahwa bakat adalah satu-satunya sumber daya perusahaan yang dapat memberikan dasar untuk keunggulan kompetitif yang berkelanjutan, oleh karena itu, organisasi harus fokus pada bakat dan kemampuan yang berasal dari bakat (Pella, 2011). Peran perusahaan bukanlah penciptaan bakat atau akuisisi bakat melainkan; perusahaan dianggap sebagai lembaga integrasi bakat, karena bakat berada di kepala individu dan perusahaan hanya mengintegrasikan dan menyediakan sistem dan pengaturan struktural untuk koordinasi dan kerjasama antara pekerja berbakat (Widyanti \& Basuki, 2021).

Literatur tentang manajemen bakat menganjurkan bahwa citra dan kinerja organisasi dapat ditingkatkan, jika kemampuan individu dimanfaatkan secara akurat dan berhasil. Dalam ekonomi pengetahuan, masalah utama adalah untuk menemukan menarik, mengembangkan dan mempertahankan orang-orang berbakat, sehingga organisasi menempatkan fokus mereka untuk mendapatkan dan mempertahankan orang-orang yang kompeten dengan mereka.

\section{B. METODE}

Teknik kualitatif dengan metodologi tinjauan literatur digunakan dalam penelitian manajemen bakat sebagai keunggulan kompetitif. Penelitian kualitatif dilakukan melalui pemahaman dan penemuan untuk mengembangkan pengetahuan. Metodologi penelitian kualitatif adalah proses penyelidikan dan pemahaman berdasarkan pendekatan untuk meneliti masalah sosial dan manusia. Dalam studi ini, ilmuwan mengambil gambar yang rumit, 
menganalisis kata-kata, melaporkan secara mendalam dan mempelajari situasi yang dialami. (Moloeng, 2017).

Penelitian ini menggunakan teknik kepustakaan untuk pengumpulan data yang berkaitan dengan objek yang diteliti. Penelitian kepustakaan adalah suatu kegiatan untuk mengumpulkan, meneliti dan mengolah data kepustakaan tanpa persyaratan untuk penyelidikan lapangan (Raco, 2018).

\section{HASIL DAN PEMBAHASAN}

\section{Manajemen Bakat}

Sejumlah teori dan kerangka kerja dikembangkan terkait dengan konversi bakat menjadi kinerja yang lebih baik. Kompetensi khas perusahaan didasarkan pada sumber daya khusus, aset, kompetensi khas perusahaan terkait dengan sumber daya, aset, dan keterampilan yang dimiliki oleh anggota organisasi dan pemanfaatan sumber daya ini secara optimal membantu organisasi membangun keunggulan kompetitif. Dua teori dasar yang muncul adalah teori perusahaan: teori berbasis sumber daya dan teori berbasis bakat.

Teori berbasis bakat menyatakan bahwa bakat adalah satu-satunya sumber daya yang dapat membantu dalam memperoleh dan mempertahankan keunggulan kompetitif, dan oleh karena itu organisasi harus memusatkan perhatian pada menarik dan mempertahankan tenaga kerja berbakat. Peran perusahaan bukanlah penciptaan bakat atau akuisisi bakat melainkan; perusahaan dianggap sebagai lembaga integrasi bakat, karena bakat berada di kepala individu dan perusahaan hanya mengintegrasikan dan menyediakan sistem dan pengaturan struktural untuk koordinasi dan kerjasama antara pekerja berbakat (Widyanti \& Basuki, 2021).

Literatur keunggulan kompetitif telah berubah dan mengakui bahwa pentingnya sumber daya manusia dalam keberhasilan organisasi sangat penting (Larasati, 2018). Pendekatan berbasis sumber daya perusahaan menekankan perlunya mengembangkan sumber daya yang khas, sulit untuk ditiru dan berharga serta metode dinamis untuk mengintegrasikan sumber daya tersebut untuk keberhasilan organisasi. Perspektif berbasis sumber daya menunjukkan bahwa manfaat kompetitif tergantung pada sumber daya yang berharga, tidak biasa dan sulit untuk ditiru yang merupakan salah satu sumber daya yang langka ini dalam organisasi dan sumber daya manusia (Setiawan, 2017).

Teori perusahaan yang lebih baru, pandangan berbasis bakat perusahaan, yang memberikan pentingnya untuk mengembangkan dan meningkatkan kompetensi karyawan perusahaan melalui proses sistematis akuisisi bakat dan transfer bakat dan berbagi untuk mendapatkan keunggulan kompetitif (Lestari, 2019). Menurut pandangan berbasis sumber daya, perusahaan saingan bersaing atas dasar heterogenitas dan imobilitas sumber daya dan kemampuan mereka. Sumber daya dapat berupa fisik, manusia, dan organisasi, dan dapat digunakan untuk menerapkan strategi penciptaan nilai. Sumber daya yang berharga, langka, tidak dapat ditiru, dan tidak dapat diganti, memiliki potensi untuk memberikan keunggulan kompetitif yang berkelanjutan bagi perusahaan. Seperangkat sumber daya yang tampaknya cocok dengan kriteria di atas adalah aset bakat (Khotimah, 2017).

Hughes \& Rog (2008) menyarankan faktor-faktor tertentu yang dapat membantu keberhasilan penerapan strategi manajemen bakat. Strategi manajemen bakat harus diintegrasikan dan diselaraskan dengan strategi organisasi dan juga sangat penting untuk mengartikulasikan strategi manajemen bakat. Manajemen bakat terkait dengan budaya dan 
orang-orang dalam organisasi. Orang dan budaya adalah jantung organisasi untuk menciptakan strategi manajemen bakat yang sukses. Tantangan terbesar bagi para manajer untuk mengelola bakat bukanlah masalah teknis, melainkan budaya. Mengatasi rintangan budaya adalah tugas yang sangat sulit terutama ketika memegang pengetahuan dianggap lebih penting daripada berbagi dengan orang lain. Alasan sentimen tersebut adalah karena sifat karyawan yang kompetitif dan mereka lebih cenderung memegang pengetahuan daripada membandingkan karena terkadang mereka tidak ingin orang lain memiliki kompetensi yang sama dengan yang mereka miliki (Silze \& Dowel, 2010).

Isu penting lainnya tentang manajemen bakat adalah kompensasi, jika insentif yang tepat diberikan kepada orang-orang yang berbagi bakat maka berbagi pengetahuan menjadi efektif Sistem kompensasi dan penghargaan harus mendukung berbagi pengetahuan dan bakat. Penting untuk memberi penghargaan kepada karyawan yang berkontribusi lebih banyak dalam berbagi pengetahuan dalam organisasi dan pada saat yang sama harus memastikan bahwa karyawan memahami pentingnya manajemen bakat (Silze \& Dowel, 2010). Kesulitan dengan banyak sistem kompensasi dan insentif untuk distribusi bakat adalah bahwa bakat konstruktif berasal dari organisasi yang relatif rendah, dari orang-orang yang tidak berada dalam sistem insentif dan mungkin bereaksi jauh lebih rela terhadap perasaan bahwa mereka termasuk orang yang bermotivasi tinggi dan terdepan, kelompok orang yang inovatif. Ini mungkin pada akhirnya berarti bahwa peran penting dimainkan oleh budaya; oleh kode yang tidak dipertanyakan, bahkan dalam keadaan koma, yang membujuk berbagi bakat dan perilaku kooperatif (Bryant \& Allen, 2013).

Ada tiga komponen utama dari manajemen bakat yang menjadi sumber utama organisasi untuk mempunyai keunggulan kompetitif yaitu:

a. Atraksi dan Seleksi Bakat.

Organisasi harus menggunakan berbagai teknik dan metode untuk merekrut dan memilih bakat yang tepat. Rekrutmen kolam bakat adalah tugas pertama dan penting dari proses manajemen bakat. Kolam bakat adalah sekelompok kandidat yang merupakan calon eksekutif organisasi yang akan mengarahkan organisasi menuju kinerja kompetitif. Jadi untuk mendapatkan dan mempertahankan kinerja organisasi, rekrutmen dan seleksi individuindividu berbakat sangat penting. Pembentukan kolam bakat dapat dilakukan dalam dua bentuk, yang pertama bersifat internal dan yang kedua bersifat eksternal (Digh, 1999). Rekrutmen internal kolam bakat akan berasal dari karyawan organisasi yang sudah keluar. Rekrutmen internal dapat memberikan keuntungan karena karyawan sudah mengetahui budaya dan cara melakukan pekerjaan di organisasi dan juga dapat mengangkat moral karyawan jika posisinya. Namun, sumber eksternal akan menjadi cara terbaik untuk mengumpulkan bakat ketika organisasi ingin membawa perubahan budaya dan menginginkan.

b. Retensi bakat.

Retensi bakat adalah proses mempertahankan karyawan berbakat dengan organisasi untuk jangka waktu yang lebih lama. Pergantian bakat dari organisasi mana pun sangat merugikan karena menyebabkan penurunan produktivitas organisasi serta lebih banyak biaya untuk menarik kumpulan bakat baru. Ada dua klasifikasi retensi karyawan berbakat dengan organisasi. Intrinsik dan ekstrinsik. Insentif intrinsik mencakup beberapa penghargaan non moneter yang dapat memuaskan kebutuhan psikologis karyawan sedangkan penghargaan 
ekstrinsik adalah penghargaan moneter yang dapat membantu memenuhi kebutuhan fisiologis karyawan. Penghargaan moneter diakui sebagai alat penting untuk mempertahankan. Selanjutnya, organisasi perlu berinvestasi lebih banyak untuk tujuan mempertahankan karyawan dengan organisasi, sistem penghargaan yang baik penting untuk menarik, dan mempertahankan bakat dengan organisasi. Hal ini dapat memotivasi karyawan, sehingga menghasilkan kinerja organisasi yang tinggi (Srimulyani, 2020).

c. Pengembangan bakat.

Di era bisnis yang kompetitif dan dinamis ini, pembelajaran dan pengembangan telah menjadi tulang punggung kesuksesan, tanpa pembelajaran yang berkelanjutan, memperoleh dan mempertahankan kinerja menjadi mustahil. Pembuat strategi dan praktisi SDM mengalihkan fokus mereka ke arah pembelajaran dan pengembangan karyawan berbakat untuk meningkatkan kinerja organisasi. Pengembangan bakat adalah proses peningkatan keterampilan dan sikap karyawan. Karena bisnis terus mengubah model bisnis teknologi dan strategi baru untuk mengatasi perubahan ini, organisasi perlu meningkatkan dan meningkatkan pengetahuan karyawan. Saat membuat strategi untuk praktisi pengembangan harus memperhatikan integrasi dan kesesuaian strategis antara bakat saat ini dan keterampilan karyawan (Labola, 2019).

\section{Manajemen Bakat dan Keunggulan Kompetitif}

Tujuan utama dari setiap strategi organisasi adalah untuk meningkatkan efektivitas dan efisiensi operasi yang dapat membawa organisasi menuju kesuksesan (Efendi \&Haryati, 2021). Manajemen Bakat sangat penting ketika organisasi ingin membangun tim pemenang yang akan dibentuk oleh personel berbakat. Organisasi akan menggunakan tim semacam ini untuk memecahkan masalah atau kelemahan tertentu di departemen (Ellitan, 2002). Misalnya, jika ada masalah di Departemen Keuangan, organisasi akan membentuk tim untuk memecahkan masalah ini dan mereka akan menyelesaikannya, karena mereka adalah orang yang kompeten dan berpengalaman di bidang ini. Studi menunjukkan bahwa jika strategi organisasi dan teknologi akan menjadi kompleks, kunci keberhasilannya adalah faktor manusia. Oleh karena itu, manajer harus mempertimbangkan faktor-faktor yang mempengaruhi keberhasilan organisasi. Dalam hal ini, Lewis \& Heckman (2006) mengidentifikasi tiga aliran utama dalam menganalisis efektivitas praktik manajemen bakat. Aliran pertama mengacu pada teknik analitis untuk mengikat manajemen bakat dengan kinerja keuangan; aliran kedua menekankan proses menganalisis dan mengoptimalkan sistem manajemen bakat, dan penulis yang selaras dengan aliran ketiga tampaknya melihat analitik sebagai seperangkat metrik dan ukuran untuk digunakan oleh pengguna yang berbeda. Mempertimbangkan perspektif keuangan, peneliti menilai hubungan antara kompetensi dalam manajemen bakat dan kinerja organisasi keuangan dan menunjukkan mengapa manajemen bakat adalah investasi yang berharga. Organisasi yang menerapkan praktik manajemen bakat menunjukkan kinerja keuangan yang jauh lebih tinggi dibandingkan dengan rekan-rekan industri mereka, misalnya mengenai pendapatan dan produktivitas penjualan, Margin Laba Bersih dan Laba Sebelum Bunga, Penyusutan, dan Amortisasi Pengembalian Aset dan Return on Equity, atau Return on Shareholders' Value dan Market Value. Selain itu, berbagai penelitian mendorong penghematan biaya manajemen bakat 
melalui perencanaan suksesi internal proaktif jangka panjang dan tingkat retensi yang lebih tinggi.

Menurut penelitian yang dilakukan oleh Endratno (2013) mengeksplorasi bahwa kinerja bisnis juga dapat dipengaruhi oleh pengelolaan aset bakat. Juga diteliti bahwa ada peran besar nilai yang dihasilkan bagi pemangku kepentingan utama dengan kinerja bisnis dalam suatu organisasi. Juga diteliti bahwa proses organisasi didasarkan pada beberapa kompetensi yang digunakan untuk mengelola bisnis secara efektif dan efisien. Nilai yang dihasilkan memiliki peran besar untuk mengelola proses bisnis. Akhirnya kompetensi organisasi dikembangkan dan diproses oleh manajemen aset bakat dalam suatu organisasi. Oleh karena itu telah dijelaskan kompetensi organisasi adalah hasil dari pengelolaan aset bakat yang efektif dan efisien yang meningkatkan kinerja bisnis dan penciptaan nilai. Dengan cara yang sama efektivitas manajemen aset bakat akan memberikan perusahaan keterampilan untuk menyelaraskan permintaan pasar dengan sumber daya bakat. Kemampuan dinamis digunakan oleh perusahaan untuk mencapai konfigurasi sumber daya baru saat pasar berkembang, muncul, berkembang mati. Kemampuan dinamis lebih berguna bagi perusahaan individu untuk mendapatkan keunggulan kompetitif yang berkelanjutan dan kinerja superior jangka panjang (Sparrow \& Makram, 2015).

Telah dibersihkan dari penelitian bahwa praktik manajemen bakat memiliki peran besar untuk bersaing di pasar dan memiliki keunggulan kompetitif di pihak lain. Juga dieksplorasi bahwa organisasi hanya dapat memperoleh keunggulan kompetitif dalam rentang waktu yang singkat dengan bantuan inovasi dan teknologi baru. Ini adalah satu-satunya praktik manajemen bakat yang memberikan keunggulan kompetitif yang berkelanjutan di pasar dengan daya tarik organisasi, pengembangan, motivasi, manajemen, dan penghargaan terhadap bakat. Seperti mesin, bisnis akan gagal beroperasi dengan sukses jika elemen kunci seperti proses, sistem, dan struktur tidak selaras atau terhalang oleh gesekan antara elemen tersebut dan seperti mesin, bisnis harus dirancang, dioperasikan, dan dipelihara. Fungsifungsi ini dilakukan oleh bakat - sumber daya manusia yang digunakan oleh perusahaan. Memang, bakat (yaitu, karyawan organisasi), biasanya merupakan pengungkit terbesar untuk mendorong peningkatan kinerja bisnis. Keterampilan kolektif dari bakat yang dipekerjakan dalam suatu organisasi sebagian besar terdiri dari kemampuan inti organisasi. Bakat organisasi menyuntikkan kemampuan yang sangat sulit bagi pesaing untuk dijadikan tolok ukur dan ditiru. Lebih dari aset lainnya, bakat memberikan potensi keunggulan kompetitif jangka panjang.

\section{KESIMPULAN}

Organisasi menghadapi masalah dalam manajemen personalia dalam lingkungan bisnis yang dinamis dan kompetitif ini. Untuk bisnis yang berfungsi di tingkat internasional, manajemen bakat menjadi semakin penting. Tuntutan ditempatkan pada posisi kunci pekerja berkualifikasi tinggi karena mereka membimbing perusahaan dan membawanya ke kesuksesan tertinggi, itulah sebabnya ia berjuang untuk orang-orang terbaik. Inilah sebabnya mengapa mereka berada dalam kesuksesan tertinggi. Manajemen Bakat adalah serangkaian tindakan untuk merekrut, memilih, mengembangkan, dan mempertahankan personel penting. Mereka lebih lanjut menunjukkan bahwa manajemen bakat mengakui orang-orang yang unggul dalam aktivitas dan kinerja tertentu yang mendapat dukungan untuk memungkinkan 
mereka mendorong amplop sambil menangkap dan berbagi apa yang mereka lakukan secara berbeda sehingga rekan kerja dapat meniru mereka. Organisasi harus memiliki kemampuan dan kapasitas untuk mengenali orang-orang dan kemampuan yang dapat menciptakan nilai dan memberikan keunggulan kompetitif bagi organisasi; Selain itu, manajemen bakat juga bertujuan untuk mengembangkan dan menempatkan orang yang tepat pada pekerjaan yang tepat pada waktu yang tepat dan menyediakan lingkungan yang tepat untuk menunjukkan kemampuan mereka dengan cara terbaik bagi organisasi.

\section{DAFTAR PUSTAKA}

Bryant, P. C., \& Allen, D. G. (2013). Compensation, Benefits and Employee Turnover: HR Strategies for Retaining Top Talent. Compensation \& Benefits Review, 45(3), 171175.

Digh, P. (1999). Getting people in the pool: Diversity recruitment that works. $H R$ Magazine, 44(10), 94-98.

Efendi, S., \& Haryati, T. (2021). The Influence of Human Capital, Social Capital, and Intrinsic Motivation on Work Commitment and their Impact on Employee Performance at PT. Pos Indonesia Central Jakarta Branch. ENDLESS: International Journal of Future Studies, 4(2), 103-116.

Ellitan, L. (2002). Praktik-praktik pengelolaan sumber daya manusia dan keunggulan kompetitif berkelanjutan. Jurnal manajemen dan Kewirausahaan, 4(2), 65-76.

Endratno, H. (2013). Talent Management dalam Meningkatkan Kinerja Organisasi. Sustainable Competitive Advantage (SCA), 1(1).

Hughes, J. C., \& Rog, E. (2008). Talent Management: A Strategy For Improving Employee Recruitment, Retention And Engagement Within Hospitality Organizations. International Journal Of Contemporary Hospitality Management.

Khotimah, K. (2017). Pandangan Berbasis sumber daya (RBV) dalam pembahasan organisasi ekonomi. Future: Jurnal Manajemen dan Akuntansi, 5(1), 31-41.

Krissetyanti, E. P. L. (2013). Penerapan Strategi Manajemen Bakat Dalam Pengembangan Pns. Civil Service Journal, 7(1).

Labola, Y. A. (2019). Konsep Pengembangan Sumber Daya Manusia Berbasis Kompetensi, Bakat dan Ketahanan dalam Organisasi. Jurnal Manajemen \& Kewirausahaan, 7(1), 28-35.

Larasati, S. (2018). Manajemen Sumber Daya Manusia. Deepublish.

Lestari, E. R. (2019). Manajemen Inovasi: Upaya Meraih Keunggulan Kompetitif. Universitas Brawijaya Press.

Lewis, R. E., \& Heckman, R. J. (2006). Talent Management: A Critical Review. Human Resource Management Review, 16(2), 139-154.

Moloeng, J. L. (2017). Metodologi Penelitian Kualitatif Edisi Revisi. Bandung: PT. Remaja Rosdakarya.

Pella, D. A. (2011). Talent Management: Building Human Capital for Growth \& Excellence. Gramedia Pustaka Utama.

Raco, J. (2018). Metode Penelitian Kualitatif: Jenis, Karakteristik Dan Keunggulannya. Osfo.

Schuler, R. S. (2015). The 5-C framework for managing talent. Organizational Dynamics, 44(1), 47-56.

Setiawan, T. (2017). Pencapaian Keunggulan Kompetitif Perusahaan Dengan Pengelolaan Sumber Daya Manusianya. Media Mahardhika, 16(1), 53-64. 
Silzer, R., \& Dowell, B. E. (2010). Strategic Talent Management Matters. Strategy-Driven Talent Management: A Leadership Imperative, 3-72.

Sparrow, P. R., \& Makram, H. (2015). What is the value of talent management? Building value-driven processes within a talent management architecture. Human resource management review, 25(3), 249-263.

Srimulyani, V. A. (2020). Talent Management dan Konsekuensinya terhadap Employee Engagement dan Employee Retention. INOBIS: Jurnal Inovasi Bisnis dan Manajemen Indonesia, 3(4), 538-552.

Sule, E. T., \& Wahyuningtyas, R. (2016). Manajemen Bakat Terintegrasi. Penerbit Andi.

Widyanti, R., \& Basuki, M. S. (2021). Perilaku Organisasi (Teori dan Konsep) Jilid 1 (Vol. 207). Media Sains Indonesia. 